Vol.26 No.1, Juni 2020

ISSN (p): 1693-590x, ISSN (e): 2686-4711

DOI: $10.36309 /$ goi.v26i1.122

\title{
Aplikasi Wisata Kabupaten Sragen Berbasis Android
}

\author{
Hartati Dyah Wahyuningsih*1, Widyo Ari Utomo ${ }^{2}$, Barradita Sanjaya ${ }^{3}$ \\ ${ }^{1,3}$ Program Studi Sistem Informasi, STMIK AUB, Surakarta, Indonesia \\ ${ }^{2}$ Program Studi Sistem Komputer, STMIK AUB, Surakarta, Indonesia \\ e-mail:*1'hartati.dyah@stmik-aub.ac.id, ${ }^{2}$ widyoari@stmik-aub.ac.id, \\ 3paparockstreet@gmail.com
}

\begin{abstract}
Abstrak
Dalam penelitian ini membahas tentang informasi wisata yang ada di Kabupaten Sragen dengan total luas wilayah 941.55 KM2. Kabupaten Sragen juga sering disebut sebagai "Tlatah Sukowati". Kurangnya informasi wisata yang ada yang sebagian belum banyak di expose oleh media cetak dan elektronik oleh sebab itu wisatawan yang ingin berkunjung ke Kabupaten Sragen akan sedikit kebingungan dalam mencari informasi wisata yang ada. Tujuan penelitian merancang dan membangun Aplikasi Wisata Kabupaten Sragen Berbasis Android, Dengan mengunakan metode waterfall.

Perancangan sistem menggunakan bahasa pemrograman java dan PHP versi 5.6.8, Android Studio versi 2.2.3, UML, database MySQL versi 5.6.21. Hasil dari aplikasi wisata kabupaten Sragen diharapkan dapat memberikan solusi bagi para wisatawan dengan memanfaatkan integrasi GPS (Global Positioning System), serta layanan petunjuk jalan dari Google Map yang menghasilkan informasi seputar wisata yang di tampilkan pada aplikasi wisata sragen atau hanya ingin sekedar melihat informasi wisata yang ada.
\end{abstract}

Kata kunci- Wisata, Kabupaten Sragen, Aplikasi Android, Android Studio versi 2.2.3, GPS.

In this study discusses the existing tourist information in Sragen regency with a total area of 941.55 KM2. Sragen regency is also often referred to as "Tlatah Sukowati". Lack of existing tourist information that some have not been exposed by many print and electronic media therefore tourists who want to visit Sragen regency will be a little confused in searching for existing tourist information. The purpose of research to design and build Tourist Applications Sragen Based Android, By using the method waterfall.

System design using java programming language and PHP version 5.6.8, Android Studio version 2.2.3, UML, MySQL database version 5.6.21. The result of Sragen regency tourism application is expected to provide a solution for the tourists by utilizing the integration of GPS (Global Positioning System), as well as service directions from the Google Map that produces information about the tour that is displayed on the application sragen tour or just want to just see the tourist information there is.

Keywords - Kabupaten Sragen, Android Application, Android Studio version 2.2.3, GPS.

\section{PENDAHULUAN}

Perkembangan internet sangat pesat, hal ini dimanfaatkan para produsen smartphone yang berlomba-lomba membuat alat bantu komunikasi yang sangat praktis dan fleksibel yaitu smartphone. Khususnya pada smartphone berbasis android yang bersifat opensource bagi 
pengembang untuk menciptakan ataupun mengembangkan aplikasi baru. Android adalah sebuah sistem operasi untuk perangkat mobile berbasis linux yang mencakup sistem operasi, middleware. (Safaat, 2012). Oleh karena itu adanya keterbatasan dari aplikasi pihak ketiga untuk mendapatkan data asli ponsel, berkomunikasi antar proses serta keterbatasan distribusi aplikasi pihak ketiga untuk platform mereka. (Stepanus, 2011)

Pariwisata adalah suatu kegiatan yang berhubungan dengan perjalanan rekreasi, Menurut Undang-Undang No.10 tahun 2009 tentang kepariwisataan, pariwisata adalah berbagai macam kegiatan wisata dan didukung oleh berbagai fasiltas serta layanan yang disediakan masyarakat, pengusaha, pemerintah, dan pemerintah daerah. Berdasarkan dua pengertian tersebut dapat disimpulkan bahwa pariwisata merupakan kegiatan wisata atau rekreasi yang didukung oleh berbagai macam fasilitas dan layanan.

Sektor pariwisata merupakan salah satu sektor andalan kegiatan perekonomian yang berorientasi pada perluasan lapangan kerja dan kesempatan kerja. Sejalan dengan usaha pemerintah dalam mencapai sasaran pembangunan. Pengembangan sektor pariwisata saat ini mendapat perhatian serius karena selain untuk menciptakan lapangan kerja, pembangunan pariwisata mampu menggalakkan kegiatan ekonomi lainnya, termasuk pendapatan daerah dan negara serta penerimaan devisa.

Sragen merupakan sebuah Kabupaten di Jawa Tengah, Kabupaten ini memiliki sejuta pesona dan panorama alam yang menakjubkan dan masih banyak yang tersembunyi, sehingga masih banyak orang yang belum mengetahui akan keindahan objek wisata yang ada di Sragen. Sragen mempunyai banyak objek wisata mulai dari situs budaya, situs bersejarah, sampai air terjun yang sangat memanjakan mata dan bisa menjadi tujuan wisatawan untuk segera dikunjungi.

Menurut Badan Pusat Statistik Kabupaten Sragen, jumlah wisatawan pada beberapa tempat wisata di Sragen rata-rata setiap tahunnya mengalami peningkatan jumlah wisatawan, namun belakangan ini pada akhir tahun 2016 sampai dengan tahun 2018 mengalami penurunan jumlah wisatawan. Berikut adalah contoh statistik data pengunjung pada tempat wisata museum sangiran, pada tahun 2011 jumlah wisatawan 134.034 pengunjung, pada tahun 2012 naik menjadi 355.798 pengunjung, pada tahun 2013 naik lagi menjadi 425,651 pengunjung dan akhir 2016 sampai dengan awal bulan 2018 jumlah kunjungan wisatawan menjadi 227.131 pengunjung. (www.sragenkab.bps.go.id)

Banyaknya tempat wisata di Kabupaten Sragen, namun tidak diimbangi dengan pemberian informasi yang cukup untuk wisatawan mengenai tempat tujuan wisata mereka. Minimnya informasi ini membuat banyak masyarakat mencari informasi mengenai tempat wisata melalui brosur, referensi teman atau saudara, buku dan terutama melalui internet. Kesulitan masyarakat dalam mengakses informasi mengenai tempat wisata berkutat pada hal yang sama yaitu biaya transportasi, makan, budaya, tenpat menginap, objek wisata dan banyak hal lainnya. Tidak jarang hanya untuk mencari informasi tersebut wisatawan menghabiskan banyak waktu berjam-jam dan informasi yang mereka dapatkan tidak memuaskan.

Pada saat ini para wisatawan memerlukan informasi objek wisata dan fasilitas yang ada dilokasi objek wisata yang lebih lengkap. Tidak hanya informasi mengenai tempat wisatanya saja, tetapi juga informasi mengenai lokasi tempat wisata itu berada, hotel/penginapan, tempat kuliner dan layanan umum seperti pom bensin, ATM, Bank, rumah sakit dan kantor polisi yang ada di sekitar tempat wisata tersebut. Data di peroleh dari tagar analisis (\#)wisatasragen 4.455 kiriman publik melalui sosial media instagram. Sehingga masyarakat netizen mendapatkan informasi.

Dengan adanya kasus tersebut penulis ingin membuat sebuah aplikasi wisata android, yang dapat menjadi media informasi bagi wisatawan dalam menemukan lokasi tempat wisata dengan mudah dan mengenali tempat wisata yang ada di Sragen lebih jelas dan menarik beserta fasilitas-fasilitas umum lainnya, serta mampu mempromosikan tempat wisata yang ada di Kabupaten Sragen secara maksimal, dapat meningkatkan jumlah kunjungan wisatawan dan memperkenalkan lebih luas dan cepat pariwisata di Kabupaten Sragen. Untuk selanjutnya dalam 
penyusunan penelitian ini penulis menyajikan judul "Aplikasi Wisata Kabupaten Sragen Berbasis Android".

\section{METODE PENELITIAN}

\subsection{Analisis Sistem}

Untuk Pengembangan sistem informasi dilakukan untuk menyelesaikan masalah yang terjadi pada suatu organisasi, terutama untuk masalah-masalah yang menyangkut ketersediaan informasi bagi pengambil keputusan dalam organisasi tersebut. Masalah tersebut dapat diidentifikasi dari analisa PIECES (Performance, Information, Economics, Control, Efficiency, dan Service) yang diusulkan oleh James Wetherbe dalam bukunya Systems Analysis and Design : Traditional, Best Practices 4th Ed. James Wetherbe menyebutkan bahwa tujuan dari analisis PIECES ini adalah untuk mengoreksi atau pemperbaiki system (Prasetyo, 2015).

\subsection{Perancangan Sistem}

1. Flowchart sistem aplikasi wisata Sragen oleh admin website

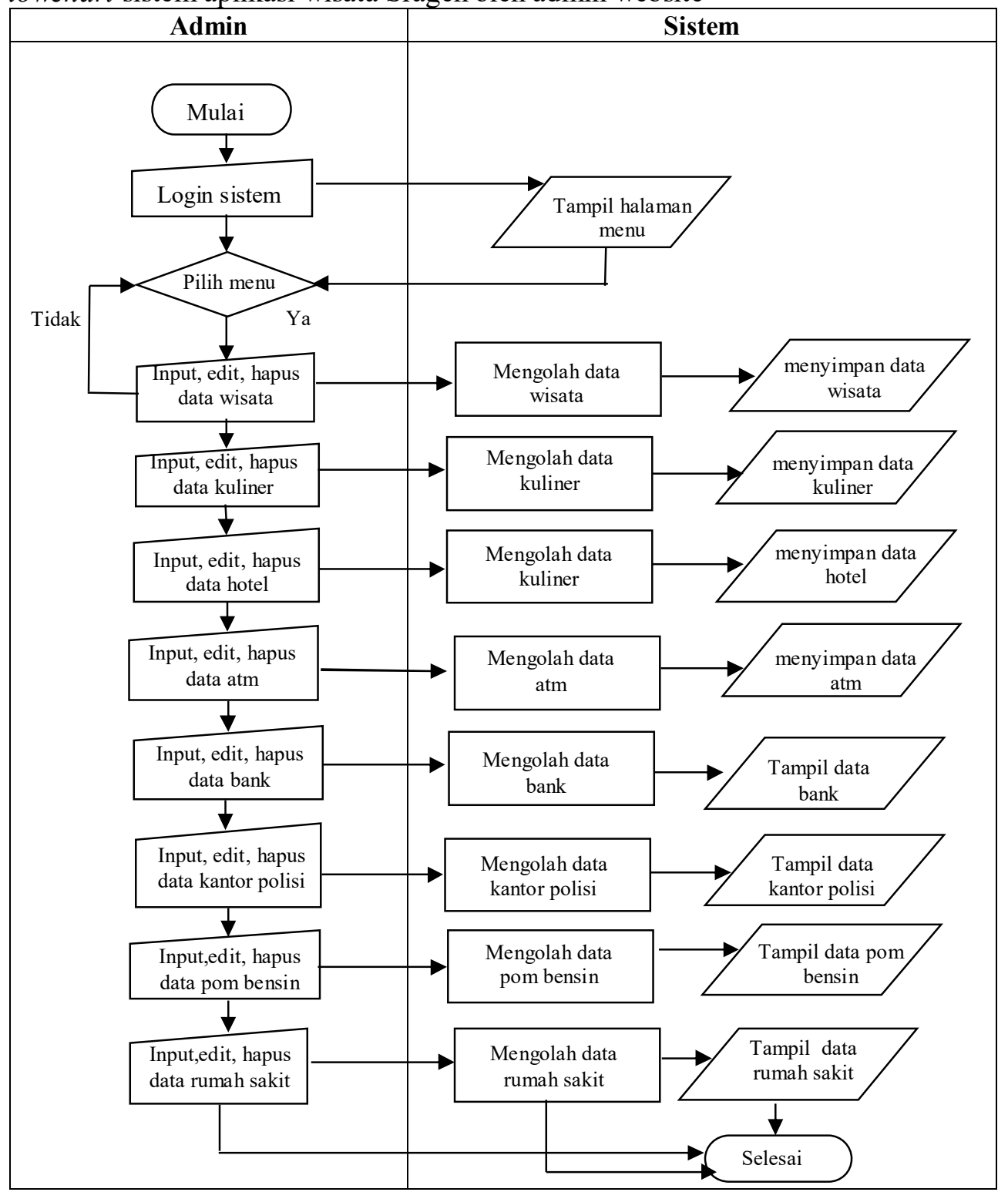

Gambar 1. Flowchart sistem aplikasi wisata Sragen oleh admin website 
2. Flowchart sistem aplikasi wisata Sragen user android

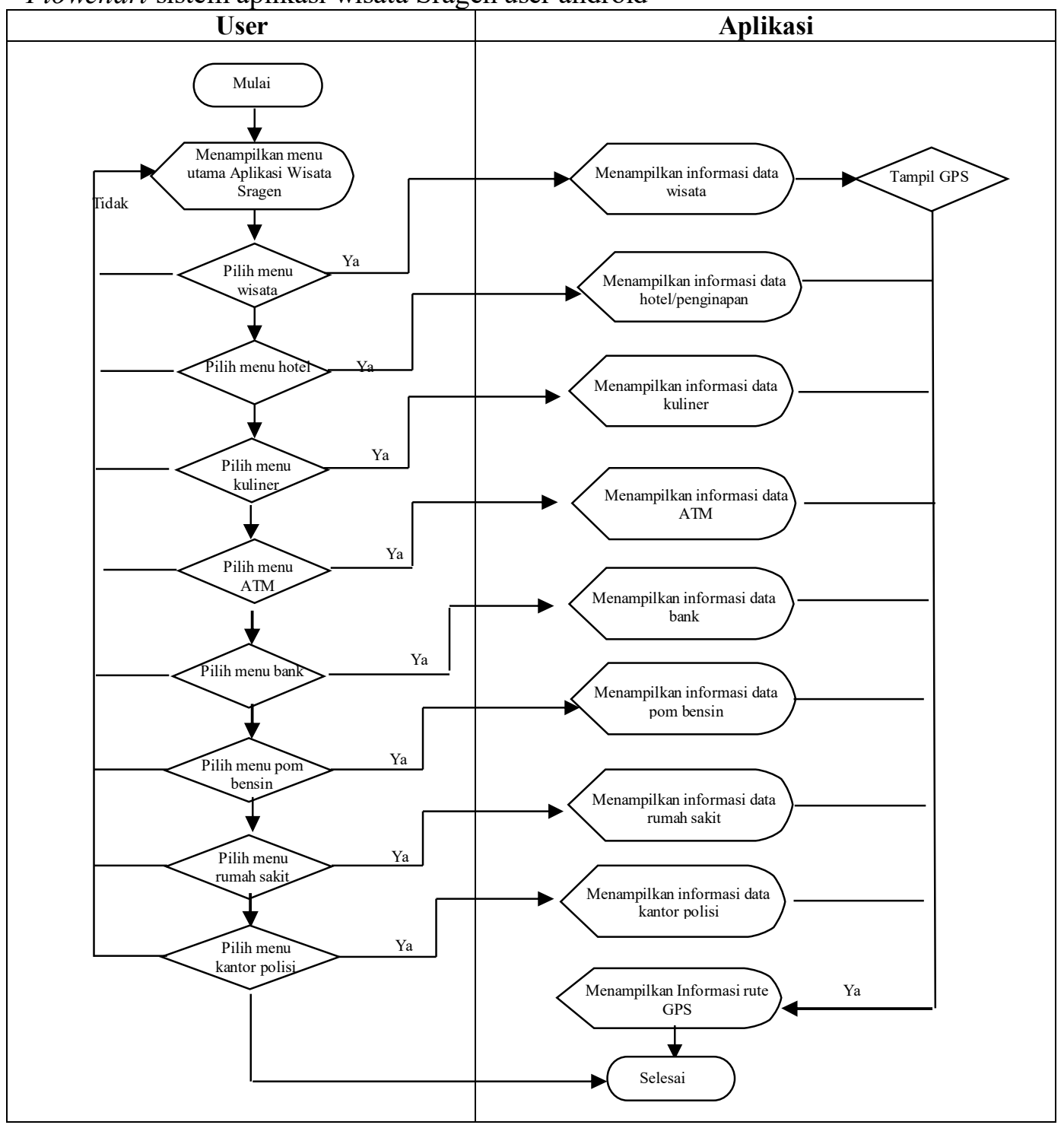

Gambar 2. Flowchart sistem yang dibangun data Sragen user

\subsection{Use Case Diagram}

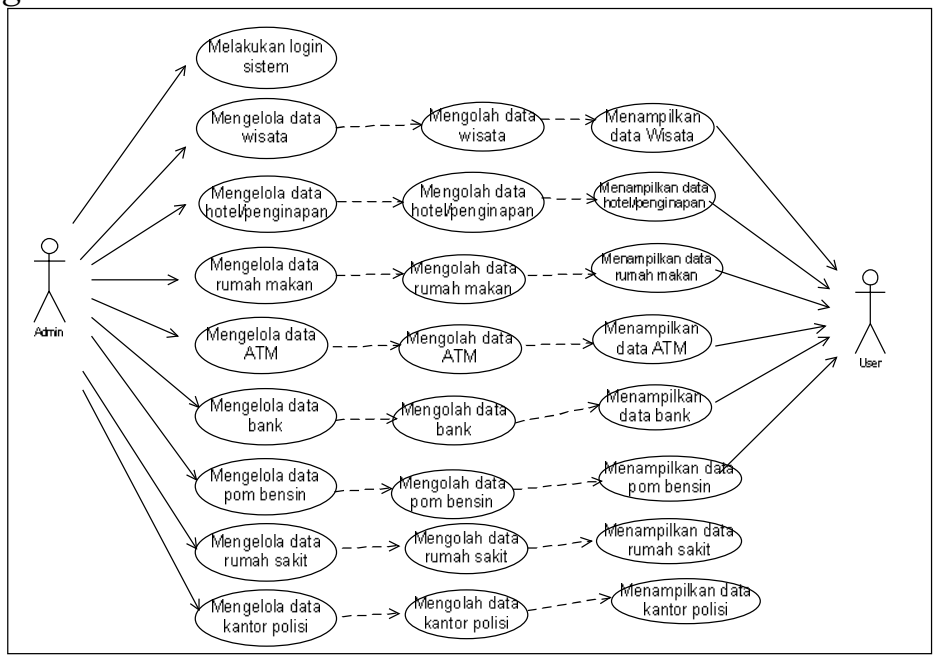

Gambar 3. Use Case Diagram 


\subsection{Class Diagram}

Class diagram adalah diagram yang digunakan untuk menampilkan beberapa kelas serta paket-paket yang ada dalam sistem atau perangkat lunak yang sedang dikembangkan. Class diagram memberikan gambaran atau diagram statis tentang sistem atau perangkat lunak dan relasi-relasi yang ada didalamnya. Berikut Class Diagram Aplikasi Tempat Wisata Kabupaten Sragen Berbasis Android Gambar 4.

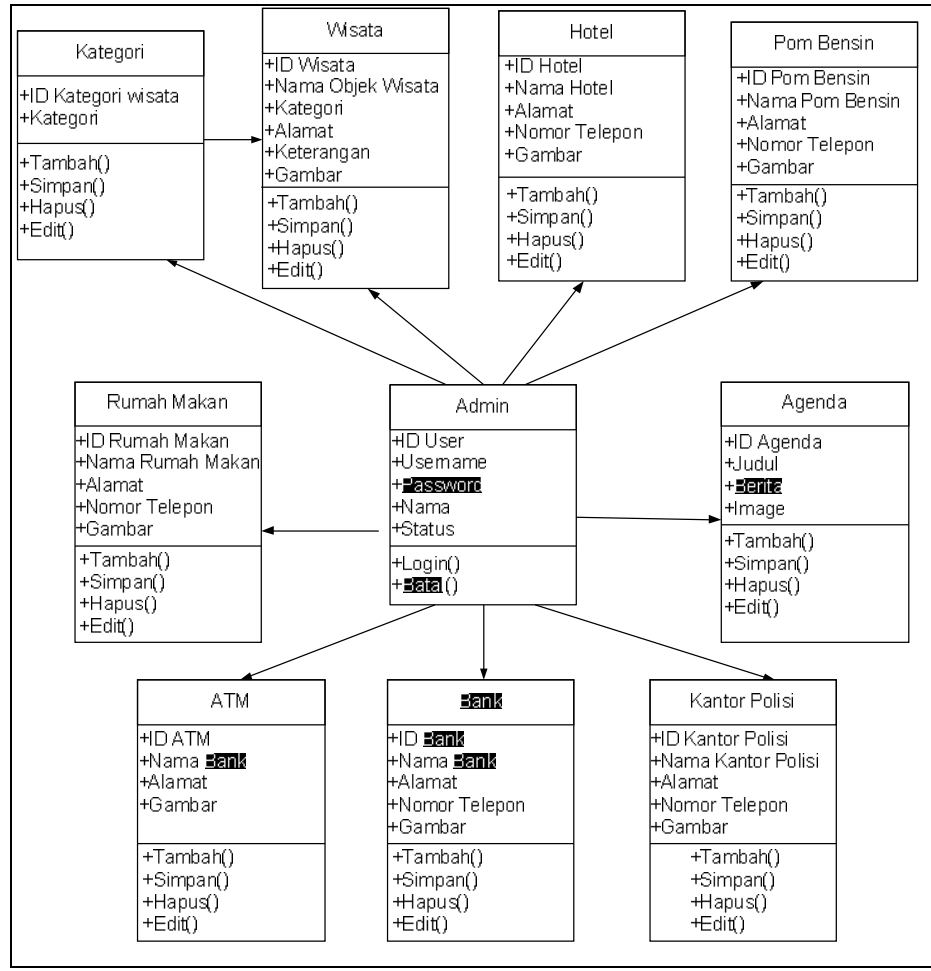

Gambar 4. Class Diagram Prima Nerstation

\section{HASIL DAN PEMBAHASAN}

\subsection{Uji Coba Sistem}

Pada bagian ini menguraikan tentang tahapan-tahapan dalam melakukan pengujian terhadap sistem dan program yang sudah dibuat, sehingga sistem tersebut bebas dari kesalahan agar dapat dilanjutkan pada proses selanjutnya yaitu implementasi sistem dengan menggunakan blackbox testing sebagai metode pengujian sistem seperti Tabel 1.

Tabel 1. Pengujian Blackbox

\begin{tabular}{|l|l|l|l|c|}
\hline No & $\begin{array}{c}\text { Fungsi yang } \\
\text { diuji }\end{array}$ & \multicolumn{1}{|c|}{$\begin{array}{c}\text { Hasil yang } \\
\text { diharapkan }\end{array}$} & \multicolumn{1}{|c|}{ Pengamatan } & Kesimpulan \\
\hline 1 & Login admin & $\begin{array}{l}\text { Memasukkan } \\
\text { username dan } \\
\text { password }\end{array}$ & $\begin{array}{l}\text { Berhasil masuk ke } \\
\text { halaman utama }\end{array}$ & Benar \\
\hline 2 & Menu atm & Membuka data atm & $\begin{array}{l}\text { Sistem menampilkan } \\
\text { data atm }\end{array}$ & Benar \\
\hline 3 & $\begin{array}{l}\text { Tambah data } \\
\text { atm }\end{array}$ & $\begin{array}{l}\text { Menyimpan data atm } \\
\text { kedalam database }\end{array}$ & $\begin{array}{l}\text { Data atm berhasil } \\
\text { disimpan }\end{array}$ & Benar \\
\hline 4 & Edit data atm & $\begin{array}{l}\text { Memperbaharui data } \\
\text { atm baru }\end{array}$ & $\begin{array}{l}\text { Sistem berhasil } \\
\text { mengubah data atm }\end{array}$ & Benar \\
\hline 5 & $\begin{array}{l}\text { Hapus data } \\
\text { atm }\end{array}$ & Menghapus data atm & $\begin{array}{l}\text { Sistem berhasil } \\
\text { menghapus data atm }\end{array}$ & \\
\hline
\end{tabular}




\begin{tabular}{|c|c|c|c|c|}
\hline 6 & Menu bank & Membuka data bank & $\begin{array}{l}\text { Sistem menampilkan } \\
\text { data bank }\end{array}$ & Benar \\
\hline 7 & $\begin{array}{l}\text { Tambah data } \\
\text { bank }\end{array}$ & $\begin{array}{l}\text { Menyimpan data } \\
\text { bank kedalam } \\
\text { database }\end{array}$ & $\begin{array}{l}\text { Data bank berhasil } \\
\text { disimpan }\end{array}$ & Benar \\
\hline 8 & Edit data bank & $\begin{array}{l}\text { Memperbaharui data } \\
\text { bank baru }\end{array}$ & $\begin{array}{l}\text { Sistem berhasil } \\
\text { mengubah data bank }\end{array}$ & Benar \\
\hline 9 & $\begin{array}{l}\text { Hapus data } \\
\text { bank }\end{array}$ & Menghapus data bank & $\begin{array}{l}\text { Sistem berhasil } \\
\text { menghapus data bank }\end{array}$ & Benar \\
\hline 10 & Menu hotel & Membuka data hotel & $\begin{array}{l}\text { Sistem menampilkan } \\
\text { data hotel }\end{array}$ & Benar \\
\hline 11 & $\begin{array}{l}\text { Tambah data } \\
\text { hotel }\end{array}$ & $\begin{array}{l}\text { Menyimpan data } \\
\text { hotel kedalam } \\
\text { database }\end{array}$ & $\begin{array}{l}\text { Data hotel berhasil } \\
\text { disimpan }\end{array}$ & Benar \\
\hline 12 & Edit data hotel & $\begin{array}{l}\text { Memperbaharui data } \\
\text { hotel baru }\end{array}$ & $\begin{array}{l}\text { Sistem berhasil } \\
\text { mengubah data hotel }\end{array}$ & Benar \\
\hline 13 & $\begin{array}{l}\text { Hapus data } \\
\text { hotel }\end{array}$ & Menghapus data hotel & $\begin{array}{l}\text { Sistem berhasil } \\
\text { menghapus data hotel }\end{array}$ & Benar \\
\hline 14 & Menu kuliner & $\begin{array}{l}\text { Membuka data } \\
\text { kuliner }\end{array}$ & $\begin{array}{l}\text { Sistem menampilkan } \\
\text { data kuliner }\end{array}$ & Benar \\
\hline 15 & $\begin{array}{l}\text { Tambah data } \\
\text { kuliner }\end{array}$ & $\begin{array}{l}\text { Menyimpan data } \\
\text { kuliner kedalam } \\
\text { database }\end{array}$ & $\begin{array}{l}\text { Data kuliner berhasil } \\
\text { disimpan }\end{array}$ & Benar \\
\hline 16 & $\begin{array}{l}\text { Edit data } \\
\text { kuliner }\end{array}$ & $\begin{array}{l}\text { Memperbaharui data } \\
\text { kuliner baru }\end{array}$ & $\begin{array}{l}\text { Sistem berhasil } \\
\text { mengubah data kuliner }\end{array}$ & Benar \\
\hline 17 & $\begin{array}{l}\text { Hapus data } \\
\text { kuliner }\end{array}$ & $\begin{array}{l}\text { Menghapus data } \\
\text { kuliner }\end{array}$ & $\begin{array}{l}\text { Sistem berhasil } \\
\text { menghapus data kuliner }\end{array}$ & Benar \\
\hline 18 & Menu polisi & Membuka data polisi & $\begin{array}{l}\text { Sistem menampilkan } \\
\text { data polisi }\end{array}$ & Benar \\
\hline 19 & $\begin{array}{l}\text { Tambah data } \\
\text { polisi }\end{array}$ & $\begin{array}{l}\text { Menyimpan data } \\
\text { polisi kedalam } \\
\text { database }\end{array}$ & $\begin{array}{l}\text { Data polisi berhasil } \\
\text { disimpan }\end{array}$ & Benar \\
\hline 20 & $\begin{array}{l}\text { Edit data } \\
\text { polisi }\end{array}$ & $\begin{array}{l}\text { Memperbaharui data } \\
\text { kuliner baru }\end{array}$ & $\begin{array}{l}\text { Sistem berhasil } \\
\text { mengubah data polisi }\end{array}$ & Benar \\
\hline 21 & $\begin{array}{l}\text { Hapus data } \\
\text { polisi }\end{array}$ & $\begin{array}{l}\text { Menghapus data } \\
\text { kuliner }\end{array}$ & $\begin{array}{l}\text { Sistem berhasil } \\
\text { menghapus data polisi }\end{array}$ & Benar \\
\hline 22 & $\begin{array}{l}\text { Menu pom } \\
\text { bensin }\end{array}$ & $\begin{array}{l}\text { Membuka data pom } \\
\text { bensin }\end{array}$ & $\begin{array}{l}\text { Sistem menampilkan } \\
\text { data pom bensin }\end{array}$ & Benar \\
\hline 23 & $\begin{array}{l}\text { Tambah data } \\
\text { pom bensin }\end{array}$ & $\begin{array}{l}\text { Menyimpan data pom } \\
\text { bensin kedalam } \\
\text { database }\end{array}$ & $\begin{array}{l}\text { Data pom bensin } \\
\text { berhasil disimpan }\end{array}$ & Benar \\
\hline 24 & $\begin{array}{l}\text { Edit data pom } \\
\text { bensin }\end{array}$ & $\begin{array}{l}\text { Memperbaharui data } \\
\text { pom bensin baru }\end{array}$ & $\begin{array}{l}\text { Sistem berhasil } \\
\text { mengubah data pom } \\
\text { bensin }\end{array}$ & Benar \\
\hline 25 & $\begin{array}{l}\text { Hapus data } \\
\text { pom bensin }\end{array}$ & $\begin{array}{l}\text { Menghapus data pom } \\
\text { bensin }\end{array}$ & $\begin{array}{l}\text { Sistem berhasil } \\
\text { menghapus data pom } \\
\text { bensin }\end{array}$ & Benar \\
\hline 26 & $\begin{array}{l}\text { Menu rumah } \\
\text { sakit }\end{array}$ & $\begin{array}{l}\text { Membuka data } \\
\text { rumah sakit }\end{array}$ & $\begin{array}{l}\text { Sistem menampilkan } \\
\text { data rumah sakit }\end{array}$ & Benar \\
\hline 27 & $\begin{array}{l}\text { Tambah data } \\
\text { rumah sakit }\end{array}$ & $\begin{array}{l}\text { Menyimpan data } \\
\text { rumah sakit kedalam } \\
\text { database }\end{array}$ & $\begin{array}{l}\text { Data rumah sakit } \\
\text { berhasil disimpan }\end{array}$ & Benar \\
\hline
\end{tabular}




\begin{tabular}{|c|c|c|c|c|}
\hline 28 & $\begin{array}{l}\text { Edit data } \\
\text { rumah sakit }\end{array}$ & $\begin{array}{l}\text { Memperbaharui data } \\
\text { rumah sakit baru }\end{array}$ & $\begin{array}{l}\text { Sistem berhasil } \\
\text { mengubah data rumah } \\
\text { sakit }\end{array}$ & Benar \\
\hline 29 & $\begin{array}{l}\text { Hapus data } \\
\text { rumah sakit }\end{array}$ & $\begin{array}{l}\text { Menghapus data } \\
\text { rumah sakit }\end{array}$ & $\begin{array}{l}\text { Sistem berhasil } \\
\text { menghapus data rumah } \\
\text { sakit }\end{array}$ & Benar \\
\hline 30 & Menu wisata & $\begin{array}{l}\text { Membuka data } \\
\text { wisata }\end{array}$ & $\begin{array}{l}\text { Sistem menampilkan } \\
\text { data wisata }\end{array}$ & Benar \\
\hline 31 & $\begin{array}{l}\text { Tambah data } \\
\text { wisata }\end{array}$ & $\begin{array}{l}\text { Menyimpan data } \\
\text { wisata kedalam } \\
\text { database }\end{array}$ & $\begin{array}{l}\text { Data wisata berhasil } \\
\text { disimpan }\end{array}$ & Benar \\
\hline 32 & $\begin{array}{l}\text { Edit data } \\
\text { wisata }\end{array}$ & $\begin{array}{l}\text { Memperbaharui data } \\
\text { wisata baru }\end{array}$ & $\begin{array}{l}\text { Sistem berhasil } \\
\text { mengubah data wisata }\end{array}$ & Benar \\
\hline 33 & $\begin{array}{l}\text { Hapus data } \\
\text { wisata }\end{array}$ & $\begin{array}{l}\text { Menghapus data } \\
\text { wisata }\end{array}$ & $\begin{array}{l}\text { Sistem berhasil } \\
\text { menghapus data wisata }\end{array}$ & Benar \\
\hline
\end{tabular}

\subsection{Pembahasan}

Dalam pembuatan aplikasi ini dibutuhkan suatu pembahasan program untuk menguraikan program dan analisis dari hasil program yang telah dibuat.Tujuan pembahasan ini adalah untuk mengetahui apakah program yang dibuat sudah bekerja seperti yang diharapkan atau belum. Berikut adalah proses pembahasan interface atau antarmuka program:

a. Halaman login admin

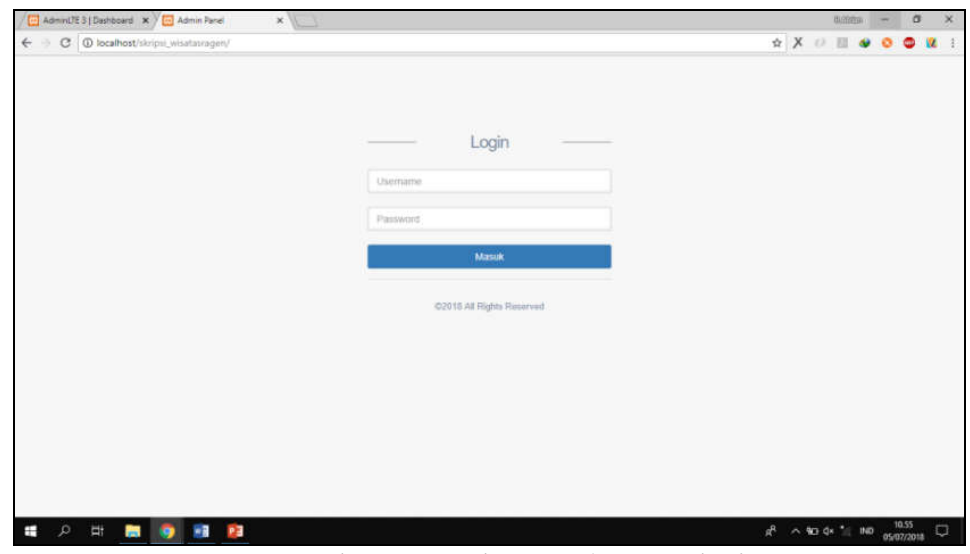

Gambar 5. Halaman login admin

Keterangan Gambar 5. Admin harus memasukkan username dan password untuk bisa masuk kedalam halaman utama admin. Setelah memasukkan username dan password kemudian pilih tombol "login"

b. Halaman beranda admin

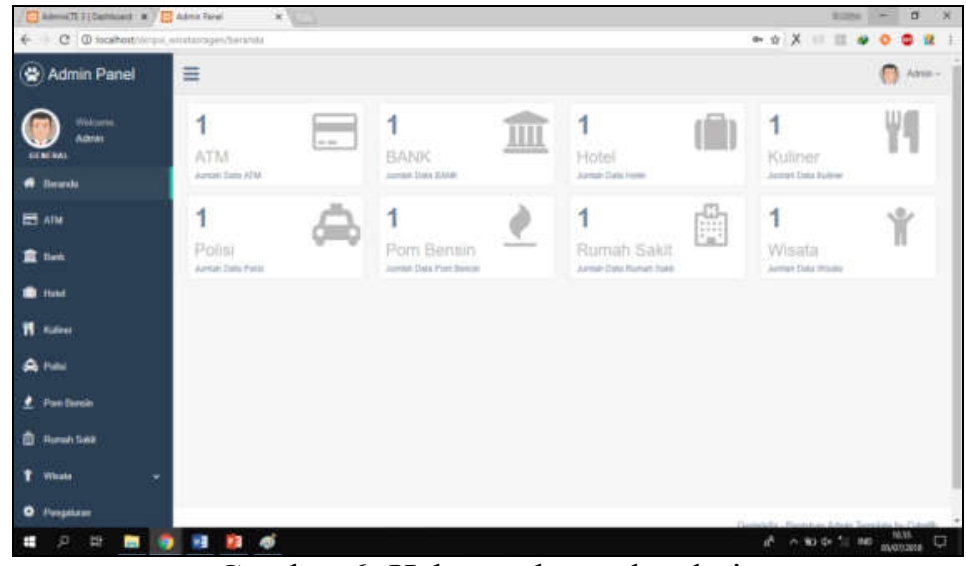

Gambar 6. Halaman beranda admin 
Pada Gambar 6. Halaman beranda admin menampilkan pilihan menu yang diolah oleh Aplikasi Wisata Sragen, data yang diolah antara lain ATM, bank, hotel, rumah makan, kantor polisi, pom bensin, rumah sakit dan wisata.

c. Halaman data atm

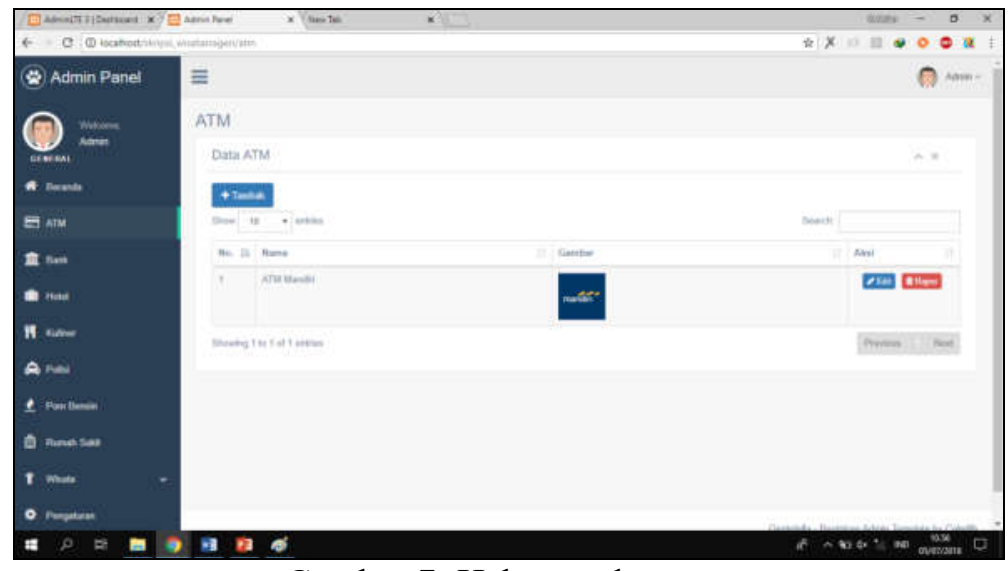

Gambar 7. Halaman data atm

Keterangan Gambar 7. Halaman data ATM menampilkan data yang diolah yaitu nama dan gambar (logo bank). Selain itu terdapat fasilitas tambah data atm, edit dan hapus data.

d. Halaman tambah wisata

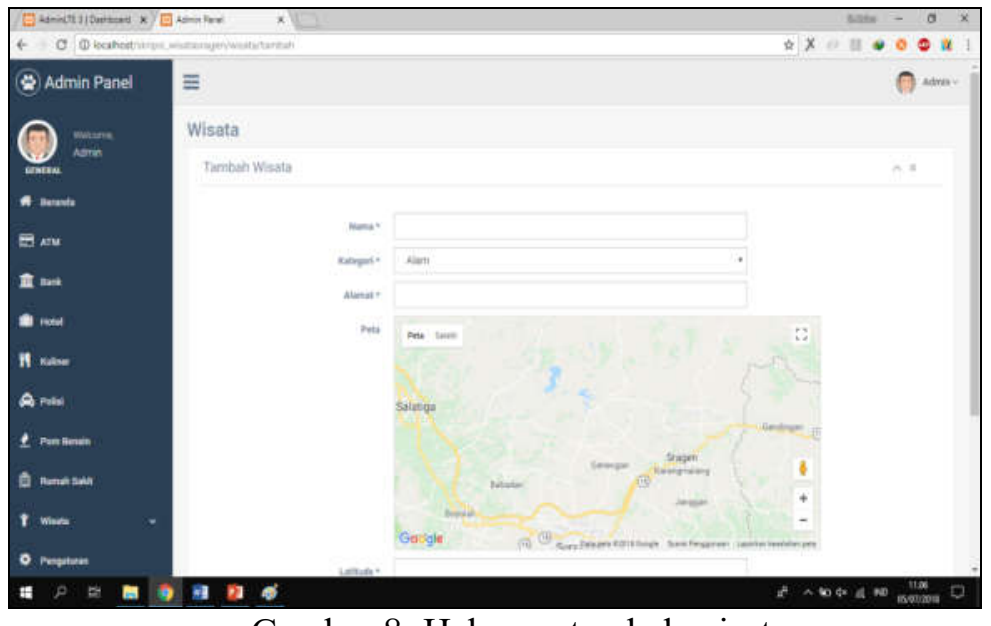

Gambar 8. Halaman tambah wisata

Keterangan Gambar 8. Halaman tambah wisata Sragen, menampilkan form yang harus diisi oleh admin yaitu nama wisata, kategori (alam/buatan), alamat, dan peta (tampil google maps).

e. Halaman data pengguna

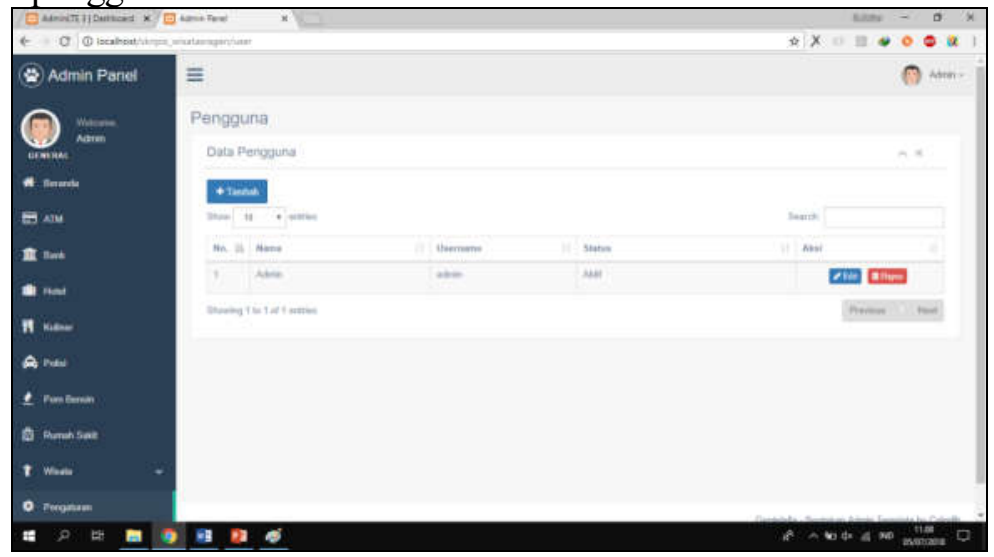

Gambar 9. Halaman data pengguna 
Keterangan Gambar 9. Halaman data pengguna atau admin merupakan halaman yang digunakan untuk mengelola data admin. data admin digunakan untuk dapat login kedalam sistem. Pada halaman ini terdapat fasilitas cari, tambah, lihat, edit dan hapus data.

f. Halaman home user

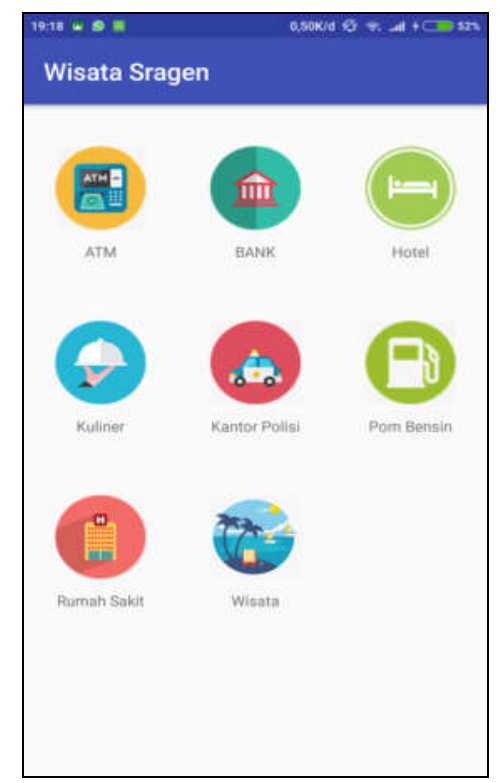

Gambar 10. Halaman home user

Keterangan Gambar 10. Halaman home user, sebagai halaman depan Aplikasi Tempat Wisata Kabupaten Sragen Berbasis Android.Pada halaman home user menampilkan informasi menu yaitu ATM, bank, hotel, kuliner, kantor polisi, pom bensin, rumah sakit dan wisata.

g. Halaman data wisata

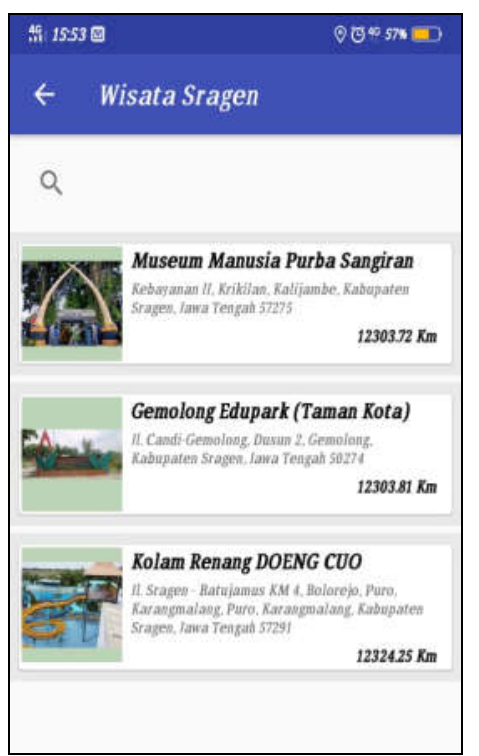

Gambar 11. Halaman data wisata

Keterangan Gambar 11. Halaman data wisata menampilkan data wisata yang ada di sekitaran tempat wisata. Terdapat informasi nama wisata, jalan dan jarak wisata tersebut. Ketika di klik pada data tersebut akan tampil google maps.

h. Halaman detail data wisata 


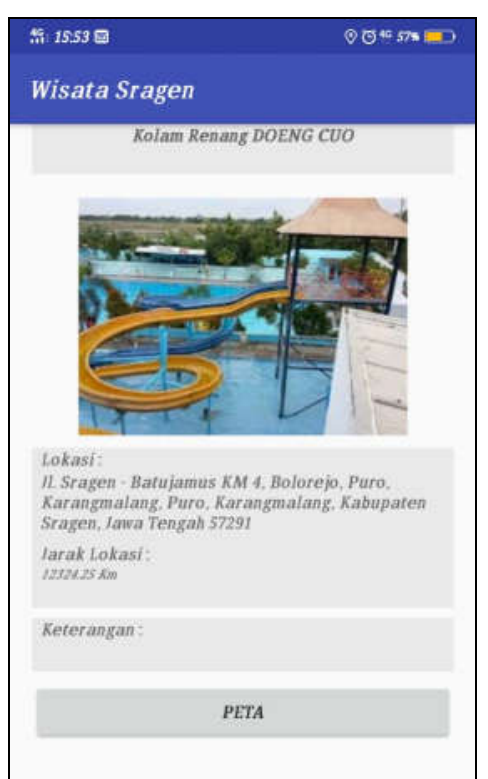

Gambar 12. Halaman detail data wisata

Keterangan Gambar 12. Halaman detail data wisata menampilkan data wisata secara detail. Informasi yang ditampilkan yaitu nama tempat wisata, foto, lokasi atau alamat keterangan dan button "Peta" yang digunakan untuk melihat peta (google maps).

\section{KESIMPULAN}

Berdasarkan penelitian yang dilakukan, diambil kesimpulan bahwa:

1. Aplikasi Wisata Kabupaten Sragen Berbasis Android digunakan sebagai media untuk promosi wisata Kabupaten Sragen, sekaligus sebagai media memberikan informasi seputar wisata Kabupaten Sragen dan fasilitas pendukung lainnya.

2. Aplikasi Wisata Kabupaten Sragen Berbasis Androidmenampilkan informasi tempat wisata, informasi rumah makan, informasi hotel/penginapan dan fasilitas pendukung seperti informasi lokasi ATM, bank, rumah sakit, pom bensin dan kantor polisi.

3. Hasil perancangan Aplikasi Wisata Kabupaten Sragen Berbasis Android menggunakan metode pengembangan sistem waterfall. Untuk perancangan proses terdiri dari flowchart sistem, usecase diagram, activity diagram, sequence diagram dan class diagram.

4. Perancangan Aplikasi Wisata Kabupaten Sragen Berbasis Android menggunakan firebase Android Studio dan database MySQL.

\section{SARAN}

Saran Aplikasi Wisata Kabupaten Sragen Berbasis Android, masih dapat dikembangkan lebih lanjut, yaitu:

1. Menambahkan fasilitas tambah data objek wisata dan fasilitas pendukung lainnya, bagi pengguna aplikasi dapat menambahkan data objek wisata yang belum ada pada aplikasi tersebut. Data dari pengguna akan tersimpan dalam halaman admin untuk dicek terlebih dahulu apabila benar maka akan di publish dalam aplikasi.

2. Menambahkan fasilitas booking hotel atau tempat kuliner, sehingga ketika dilokasi tinggal melakukan resgitrasi. 


\section{DAFTAR PUSTAKA}

[1] Anhar, 2010. Panduan Menguasai PHP \& MySQL secara otodidak. MediaKita. Jakarta Selatan.

[2] Bima, Ifnu. 2011. Aplikasi POS Berarsitektur Three Tier Menggunakan Swing, Hibernate dan Spring. Bogor.

[3] Ciqwan, 2014 Pengenalan JSON dan Prakteknya di android. Ciqwan.blog.unigha.ac.id. Pengenalan JSON dan Prakteknya diAndroid.

[4] https://www.kemenpar.go.id diakses pada 10 juli 2018 pukul 21:50

[5] https://www.sragenkab.bps.go.id diakses pada 14 Juli 2018 Pukul 21:57

[6] https://www.sublimetext.com/ diakses pada 16 Juli 2018 Pukul 20:59

[7] https://www.traveluxion.web.id di akses pada 10 juli 2018 pukul 21:43

[8] Jeffrey L. Whitten, Lonnie D. Bentley, Kevin C. 2001. System Analysis and Design Methods 5thEd. McGraw-Hill.

[9] Jogiyanto. 2005. Analisis \& Desain Sistem Informasi: Pendekatan Terstukter, Teori dan Praktis Aplikasi Bisnis. Yogyakarta: Penerbit Andi.

[10] Kadir, Abdul. 2010. Pengenalan Sistem Informasi, Ist ed. Yogyakarta: Andi Offset

[11] Kristanto. 2003. Konsep dan Perancangan Basis Data. Yogyakarta: Penerbit Andi.

[12] Mulyanto, 2008 "Rekayasa Perangkat Lunak". Direktorat Pembinaan Sekolah Menengah Kejuruan, Direktorat Jenderal Manajemen Pendidikan Dasar dan Menengah, Departemen Pendidikan Nasional.

[13] Mustika Dewi, 2013. "Sistem Informasi Pariwisata Pada Kabupaten Malang Berbasis Android". Yogyakarta: STMIK Amikom.

[14] Prabowo, Pudjo Widodo. 2011. Menggunakan UML (Unified Modelling Language) Bandung: Informatika.

[15] Prasetyo. 2015. Perancangan dan Analisis Pieces, Yogyakarta: Penerbit Graha Ilmu.

[16] Pressman, Roger S. 2001. Software Engineering : A Practitioner's Approach, Fifth Edition. The McGraw-Hill Companies, Inc, Singapore.

[17] Safaat, Nazruddin. 2012. Android Pemrograman Aplikasi Mobile Smartphone dan Tablet PC Berbasis Android. Bandung: Informatika Bandung.

[18] Stepanus, Hermawan S. 2011. Mudah Membuat Aplikasi Android. Yogyakarta: Penerbit Andi.

[19] Sugiyono. 2013. Metode Penelitian Kualitatif, Kuantitatif dan R \&D. Cetakan ke-19. Bandung: Alfabeta.

[20] Svennerberh, G. 2010. Begining Google Maps API 3. United States Of America: Appres

[21] Tulach, J. 2008. Pratical API Design: Confessions Of a Java Framework Architect. United States Of America: Appres

[22] Udayana, Tria Agus Pradnyana, Made I Agus Wirawan, Made Gede Sunarya. 2015. Pengembangan Aplikasi Panduan Pariwisata Berbasis Android Di Kabupaten Klungkung. Jurnal: Universitas Pendidikan Ganesha Singaraja, Bali.

[23] Undang Undang Dasar Republik Indonesia No. 10 Tahun 2009 tentang Kepariwisataan.

[24] Wijayanto, Agus Akhmad. 2015. Aplikasi Mobile Lokasi Objek Wisata Kota dan Kabupaten Tegal Berbasis Andorid. Skripsi: Universitas Dian Nuswantoro Semarang. 